\title{
Pictographic representation of the first dawn and its association with entheogenic mushrooms in a 16th century Mixtec Mesoamerican Codex
}

\section{Representación pictográfica del primer amanecer y su asociación con hongos enteógenos en un Códice Mesoamericano Mixteco del siglo XVI}

\author{
Faustino Hernández-Santiago', Magdalena Martínez-Reyes', Jesús Pérez-Moreno', Gerardo Mata²
}

'Colegio de Postgraduados, Campus Montecillo, Microbiología, Edafología, Km 36.5 carretera México-Texcoco, Montecillo, Estado de México, México., ${ }^{2}$ Instituto de Ecología, A. C., Carretera antigua a Coatepec No. 351, El Haya, 91070, Xalapa, Veracruz, México.

Jesús Pérez Moreno, e-mail: jperezm@colpos, jepemo@yahoo.com.mx

\section{SUMMARY}

Background: In Mexico, before the arrival of the Spaniards in the sixteenth century, mushrooms had a paramount ceremonial and sacred importance as substantiated by linguistic and archaeological evidence and documented in various pre-Hispanic codices and colonial writings. Objective: To describe a fascinating and paradoxically little known story linked to the conception of the first appearance of the sun and its relationship with entheogenic mushrooms according to the Mixtec codex "Yuta Tnoho" or "Vindobonensis Mexicanus I", produced in the XVI century.

Methods: An exhaustive bibliographic review of the publications related to Codex studied was carried out in several digital databases at the University of Sheffield, the British Library both in England, and in Colegio de Postgraduados, Mexico.

Results and conclusions: A detailed interpretation of the pictograms that register the use of entheogenic fungi is presented from a ritual and sacred perspective for the Mixtec group in pre-Hispanic times prior to the birth of the first sun. This evidence constitutes a unique indication of the cultural and ceremonial importance of mushrooms in Mesoamerica, which survives in southeastern Mexico today in groups geographically close to the Mixtecs.

Keywords: Cultural identity, Psilocybe, hallucinogenic mushrooms, pre-Hispanic codices.

\section{RESUMEN}

Antecedentes: En México, antes de la llegada de los españoles en el siglo XVI, los hongos tenían una importancia ceremonial y sagrada de gran relevancia, lo cual está sustentado en evidencias lingüísticas y arqueológicas, y documentado en códices prehispánicos y escritos coloniales.

Objetivos: Describir una historia fascinante y, paradójicamente poco conocida, vinculada a la concepción de la primera aparición del sol y su relación con los hongos enteogénos según el Códice mixteco "Yuta Tnoho" o "Vindobonensis Mexicanus I", producido en el siglo XVI.

Métodos: Se realizó una exhaustiva revisión bibliográfica de las publicaciones relacionadas con el Códice estudiado en diversas bases de datos digitales de la Universidad de Sheffield, la British Library ambas en Inglaterra y el Colegio de Postgraduados de México.

Resultados y conclusiones: Se presenta una interpretación detallada de los pictogramas que registran el uso de hongos enteógenos desde una perspectiva ritual y sagrada para los grupos Mixtecos en épocas prehispánicas previas al nacimiento del primer sol. Esta evidencia constituye una pieza única de la importancia cultural y ceremonial de los hongos en Mesoamérica, la cual pervive actualmente en el sureste de México en grupos cercanos geográficamente a los mixtecos.

Palabras clave: Identidad cultural, Psilocybe, hongos alucinógenos, códices prehispánicos. 


\section{INTRODUCTION}

Mushrooms are a characteristic element of Mexican culture. Although we do not known when they first started to be consumed, it is possible to conjecture that it began with the first groups of hunter-gatherers that inhabited the country, arriving at least 13,000 years ago from the Beringia region in Northeast Asia (Balter, 2014; Chatters et al., 2014). What is known with certainty is that at the beginning of the 16th century, when the Spaniards arrived, the knowledge of wild mushrooms was widespread, diverse and extremely detailed. This can be verified through archaeological and linguistic evidences, pre-Hispanic codices and Mesoamerican colonial writings. For example, over five thousand common names are known for edible wild fungi in different Mexican languages (Guzmán, 1997). Additionally, Mexico is currently one of the most important reservoirs of edible wild mushrooms internationally with over 450 species consumed, of which around half are sold in the markets in the centre and southeast of the country (Pérez-Moreno et al., 2008; Pérez-Moreno et al., 2010; Pérez-Moreno and Martínez-Reyes, 2014). A significant number of these fungi have bioactive compounds, which include antioxidant, anticancer, antidiabetic, antimicrobial, anti-inflammatory, and antiviral metabolites (Pérez-Moreno and Martínez-Reyes, 2014). In Mexico, more than 200 species of mushrooms used as medicine have been reported (Bautista-González, 2013). Mushrooms are also of enormous importance ceremonially (Schultes and Hoffman, 2000; Guzmán, 2008) as well as in the creation of artisanal goods and for ludic use (Garibay Orijel et al., 2006; Ruan-Soto et al., 2009, Hernández-Santiago et al., 2016).

Paradoxically, one of the most interesting attributes of mushrooms, namely its sacred link with the creation of the universe, has been poorly studied. Throughout the history of humanity there have been multiple symbolic narratives of how the world began and how the first human beings inhabited it. In the Mesoamerican area, the following stand out: i) the story of the creation of the world according to the Maya written in the Popol Vuh (Scherzer, 1857; Recinos, 1960; Christenson, 2003; Krickeberg, 2012); and ii) the story of the fifth Sun, relating the creation of the universe according to the Nahuas (Leyenda de los Soles, 1558; Jonghe, 1905; Moreno de los Arcos, 1967; Garza, 1983; León-

Portilla, 2006). Similarly to the Popol Vuh, which recounts that the corn god was the progenitor of the cosmos and of human beings, the Nahua texts relate that the god Quetzalcoatl descended to the underworld, rescued the bones of ancient humanity and created new human beings from them. In both accounts, the creation of human beings is preceded by a battle between celestial deities - the divine twins in the Mayan story, and the god Quetzalcoatl and the gods of the underworld in the Nahua tale. Florescano (1997) mentioned that both in the Náhuatl myth and in the

Popol Vuh, the supreme act of creation is not the appearance of human beings or cultivated plants but the birth of the Sun, the creative power that sets in motion the universe, which provides movement and warmth in the cosmos, initiates the passing of time and illuminates a new era in the world. In this article, we describe one of the most fascinating Mesoamerican stories, which survived countless vicissitudes over the centuries and which relates to the conception of the birth of the sun among the "na savi" (literally "the people of the rain"), also known as Mixtecs, and its relationship with entheogenic fungi.

\section{MATERIALS AND METHODS}

An exhaustive bibliographic review of the publications related to studies of the pre-Hispanic Mixtec codex "Yuta Tnoho" or "Vindobonensis Mexicanus I" was carried out. This review was conducted in several digital databases at the University of Sheffield, England, and Colegio de Postgraduados, Mexico, which included, among others, the Web of Science, Scopus and the University of Sheffield library as well as the British Library in London, England. Unstructured interviews were conducted in Mixtec communities of Oaxaca, Mexico, which allowed us to clarify various concepts related to the conception that still survives in this ethnic group. This activity was facilitated by the fact that the first author is a native speaker of Mixtec language. Based on the literature review and ethnological information, a descriptive analysis of the pictograms that appear on pages 24 and 25 of the Yuta Tnoho codex is presented, for which a careful review of the facsimile version of said codex published by Adelhofer (1963) was also conducted.

\section{RESULTS}

Among the few surviving stories related to the creation of the universe that were conceived in the pre-Hispanic era is the Mix- 
tec story in the so-called Codex Yuta Tnoho (Figure 1) or Vindobonensis Mexicanus I (Table 1). On the obverse of this codex are related the rites of corn and pulque (a millenarian sacred beverage in Mesoamerica) and the creation of plants and animals. Standing out for its profound originality, in folios 24 and 25 is found the related story of the first emergence of the Sun and its relationship with entheogenic fungi, considered a sacred element by diverse ethnic groups, among which were the Nahuas, the Mixes, the Matlatzincas and the Mazatecs in addition to the Mixtecs, prior to the arrival of the Spaniards. The story begins on the banks of the Apoala River or Yuta Tnoho, with the meeting of two nuhu (name the Mixtecs use for sacred beings even today), one red and the other golden. Then, there is a dialogue between two deities, a venerable old man and the hero of the Mixtecs people, 9-Wind or Coo Dzavui, who represents Quetzalcoatl the feathered serpent of the Mexicas. Next appears the deity 4-Lizard transformed into the sacred mushrooms to be consumed, following which 9-Wind is shown elaborately dressed and carrying on its back 4-Lizard, with three transparent mushrooms on its head. These deities go to a place where there is the precursor of corn, the god Tlaloc and the valley of the ancient dead (Figure 2). Below that is one of the most beautiful scenes of the story, where the god 9-Wind sings accompanied by music produced by scraping a bone against a human skull. In front of him, with tears in his eyes and holding in his hand two mushrooms, is the god 7-Wind or Pilzintecuhtli, the prince of flowers represented by Xochipilli among the Mexica. The tears are probably a result of the trance. In the background are shown the two nuhu who started the story accompanied on this occasion by a nocturnal insect (Figure 3) suggesting that the mushroom ceremony was carried out at night, just as it is currently performed in Mexican ethic groups.

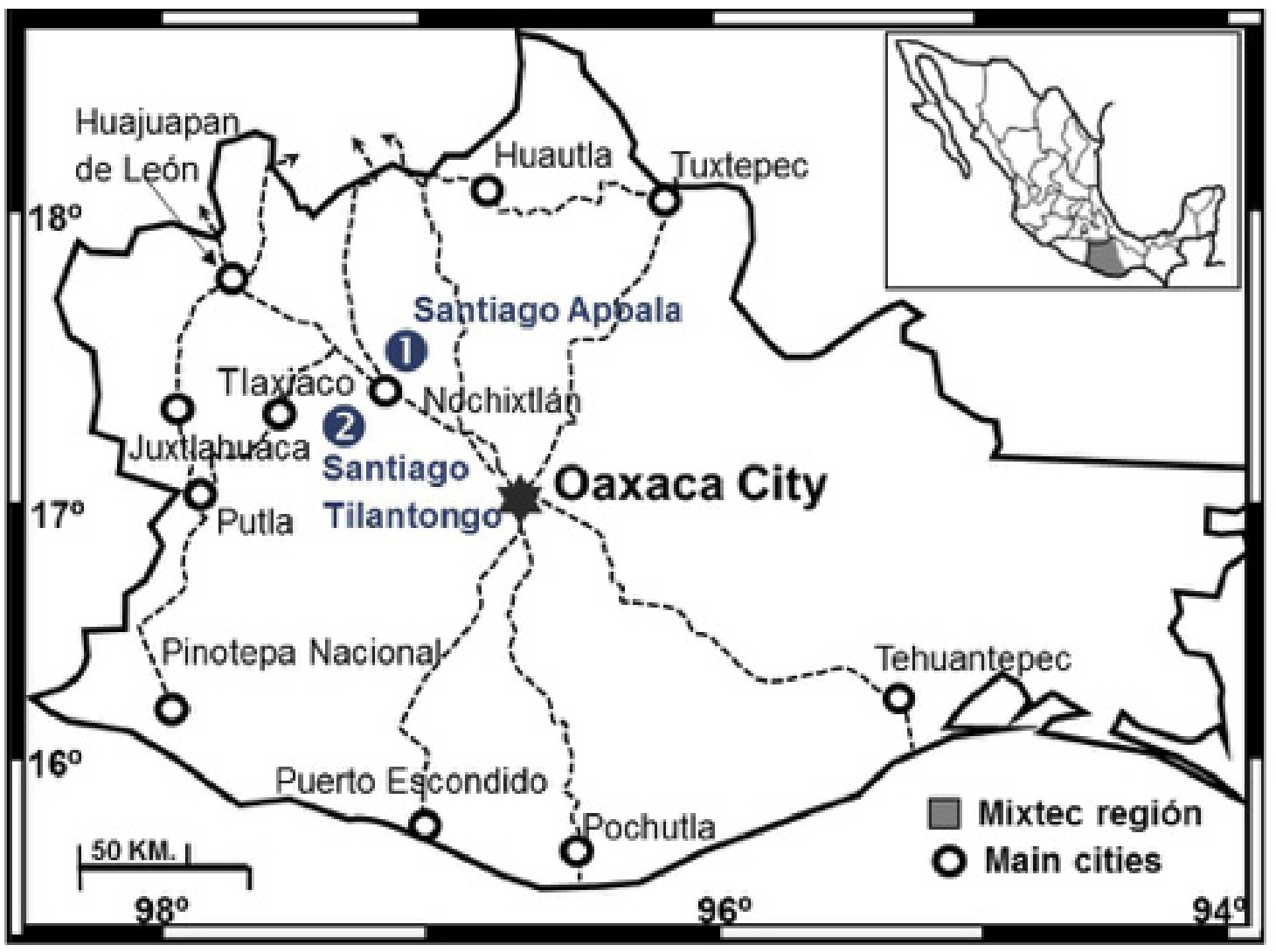

Figure 1. Geographical location of Santiago Apoala (marked inside a circle as 1) and Santiago Tilantongo (marked inside a circle as 2) places of manufacture of the Yuta Tnoho or Vindobonensis Mexicanus I Codex and distribution of the Mixtec group in Oaxaca, Mexico (located in the map in the upper right corner). 
Table 1. Cronological names assigned to the Yuta Tnoho or Vindobonensis Mexicanus I Codex

\begin{tabular}{|c|c|c|}
\hline Date & Name & Author \\
\hline 1537 & Codex Hieroglyphicorum Indiae Meridionalis & J. A. Widmanstetter \\
\hline 1655 & Hyerogliphica Mexicana & O. Worm \\
\hline 1679 & Annalium Mexicanorum & P. Lambeck \\
\hline 1690 & Codex MSts Mexicanus & D. Nessel y P. Lambeck \\
\hline 1777 & Codex Mexicanus in the Imperial Library at Vienna & W. Robertson \\
\hline 1816 & Recueil de Vienne & von Humboldt \\
\hline 1825 & Original Mexican Painting preserved in the Imperial Library at Vienna & E.K. Kingsborough \\
\hline 1901 & Mexicanische Hieroglyphen-Handschrift der k.k. Hofbibliothek in Wien & Anonymous \\
\hline 1902 & Codex de Vienne & L. Lejeal \\
\hline 1902 & Codex de la Bibliothéque de la Cour Impériale de Vienna & L. Lejeal \\
\hline 1903 & Mexicanische Bilderschrift der k.k. Hofbibliothek in Wien & E. Seler \\
\hline 1905 & Códice Clementino & W. Lehman \\
\hline 1906 & Codex Vindobonensis & E. de Jonghe \\
\hline 1917 & Große Wiener Handschrift aus Mexiko & P. Kreichgauer \\
\hline 1929 & Codex Vindobonensis Mexicanus I & W. Lehman y O. Smital \\
\hline 1941 & Codex Kreichgauer & F. Röck \\
\hline 1947 & Vienna Codex & C.A. Burland \\
\hline \multirow[t]{2}{*}{1963} & Codex Mexicanus I & O. Adelhofer \\
\hline & & Signature of the Österreichische Nationalbibliothek \\
\hline 1995 & Anales de Tepexic & G. Brotherston \\
\hline 2004 & Códice Yuta Tnoho & M. Jansen y G.A. Pérez-Jiménez \\
\hline
\end{tabular}

According to Humboldt (1816); Lejeal (1902); Lehman (1905); Jonghe (1905); Adelhofer (1963); Jansen et al. (1992); Brotherston (1995); Jansen and Pérez-Jiménez (2004).

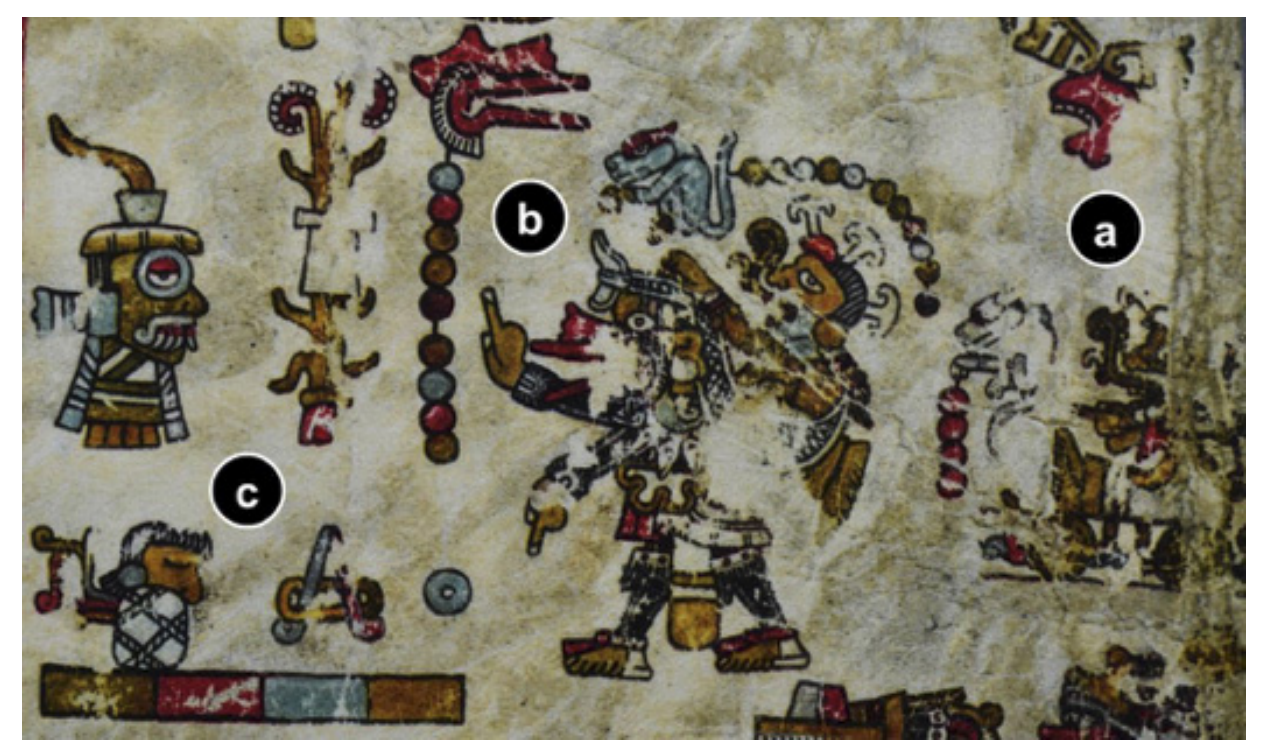

Figure 2. Representations of the mushroom deity 4-Lizard with serpentine mouth (a), and god 9-Wind carrying the goddess 11-Lizard with three transparent mushrooms on his head (b) walking towards the valley of the ancient death people where it lives the god Tlaloc and the primordial corn (c). 


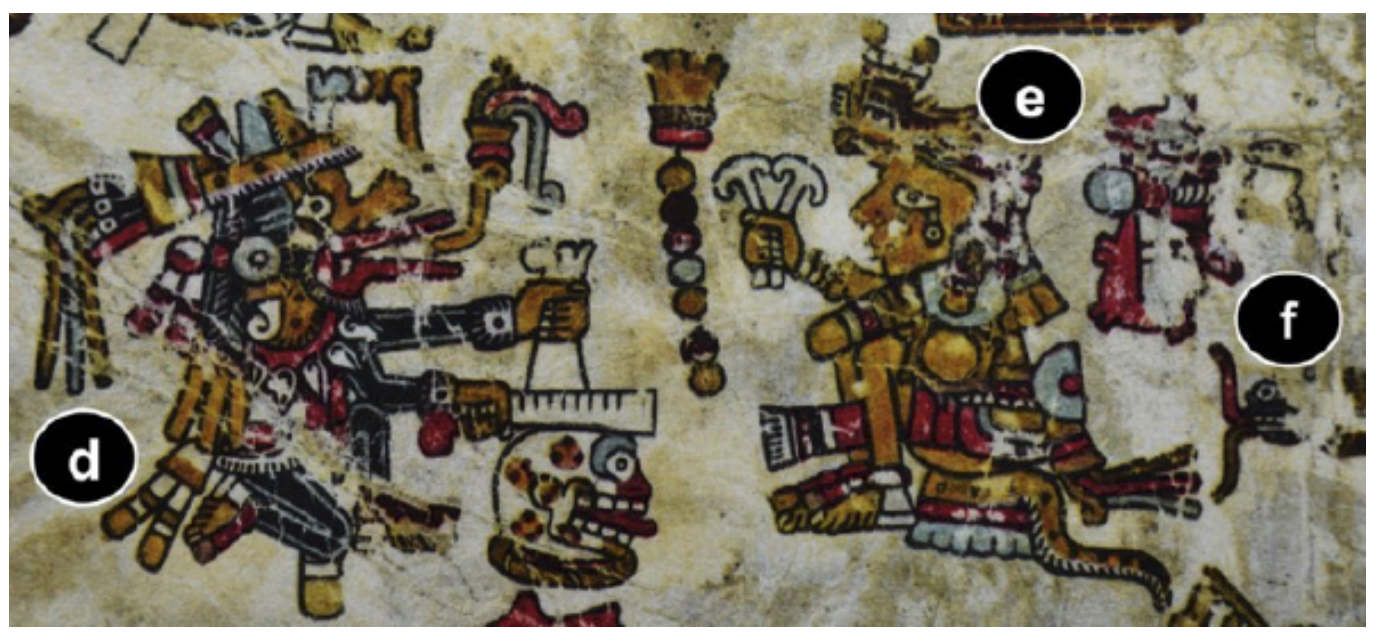

Figure 3. Beginning of the mushroom ceremony, where it is possible to appreciate the god 9-Wind, equivalent to Quetzalcoatl among the Aztecs, seated, singing and making music by scraping a bone on a human skull (d) in front of the god 7-Flower, also seated, holding in his right hand two transparent mushrooms while crying (e). At the back of the scene it is possible to see a red "ñuhu" and a black insect (f).

The story continues with the inclusion of the following elements: a mat, a throne, a cradle, a walled city, and barely perceptible to the right a singing deity, which have been interpreted as elements of a message as to how to create a good kingdom (Figure 4). Facing these elements are seven deities holding transparent mushrooms in their hands. The first one is a nameless deity painted black, which holds a pair of mushrooms. The following deities holding a pair of fungi are 1-Death, a deity not clearly identified; 9-Herb; and 1-Eagle (the lady of the rivers). In con- trast, two of the deities, 5-Flint and 4-Movement, hold only one mushroom (Figure 5). This is the only pre-Hispanic representation of a mushroom ceremony, which has survived in Mesoamerica. Then, there is a character painted black that is thrown into a cave on the Apoala River or Yuta Tnoho, to later emerge as 7-Wind, holding in his hand yellowish-brown plants or sacred mushrooms. 7-Wind is now wearing an eagle mask and two faces, each looking to another side. In front of him is 7-Movement, beautifully adorned with a jaguar head.

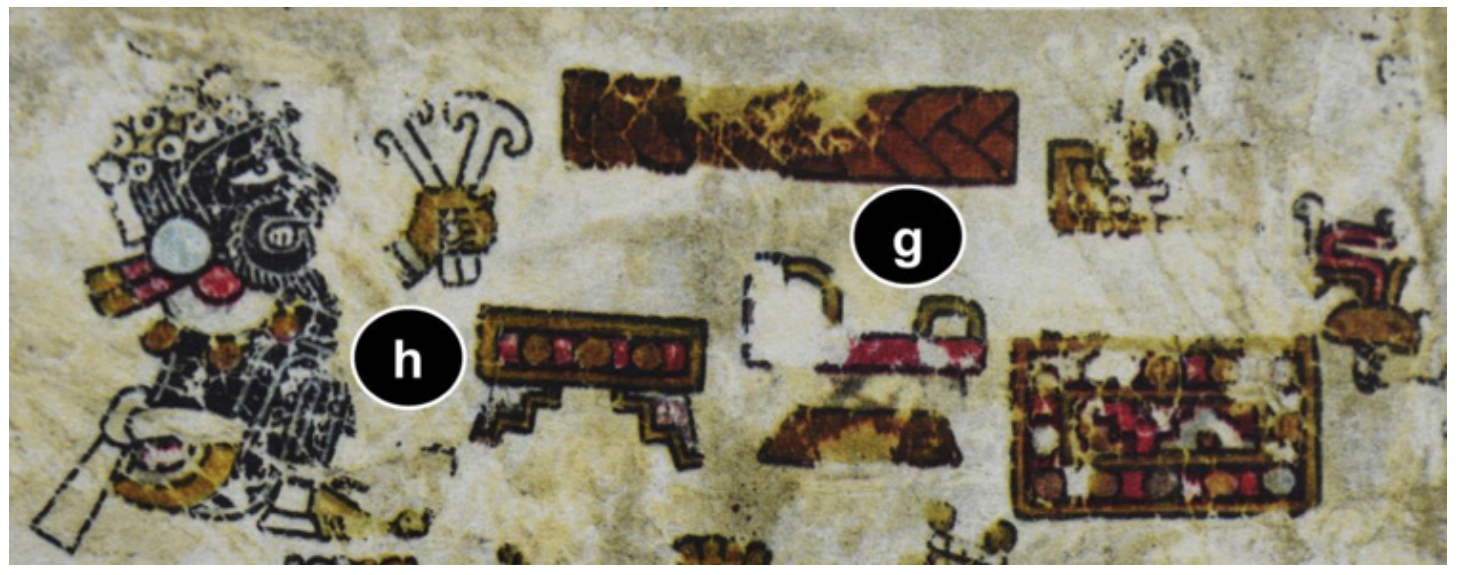

Figure 4. As a central part of the mushroom ceremony, it is possible to appreciate the participation of eight deities. Only one of them, which hold two transparent mushrooms, has no name and is painted in black (h); in front of this deity we can observe the elements that represent the new kingdom to be formed: a mat, a throne, a cradle and a walled city. At the end the symbol of a song is also appreciated $(\mathrm{g})$. 


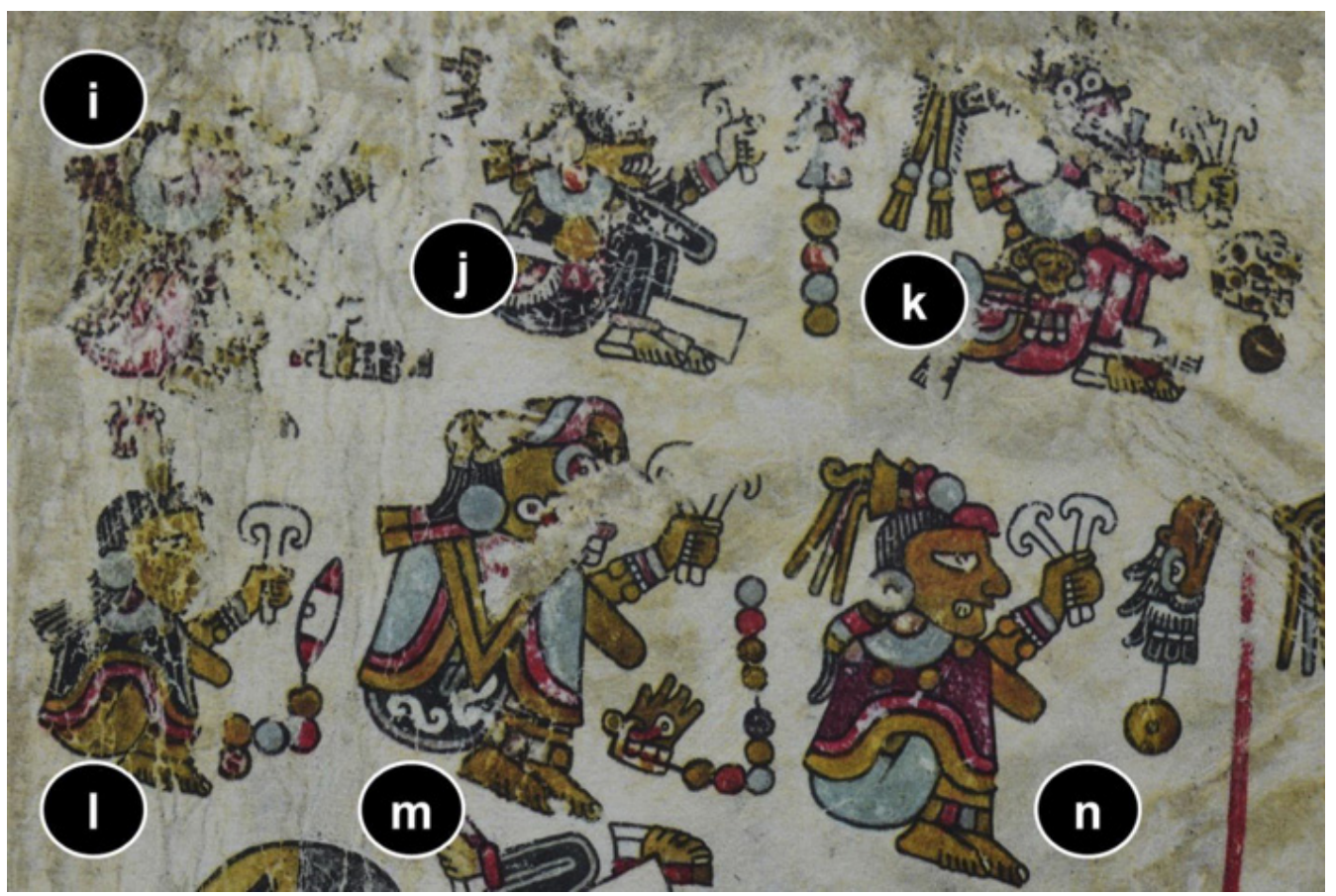

Figure 5. In the scene related to the "mushroom nocturnal meeting" the deities 1-Death (i), 4-Movement (j), a deity not clearly identified (k), 5-Flint (1), 9-Grass (m) and 1-Eagle (n) participate. All of them hold two transparent mushroom, except 5-Flint and 4-Movement, which hold only one mushroom. The best preserved is the goddess 1-Eagle (n).

Subsequently, six deities appear, but now without mushrooms. In pre-Hispanic Mexico it was believed that mushrooms could be a path to spiritual growth or rebirth. Perhaps for that reason the deities now appear changed after consuming them; some of them appear larger, others with new clothes or with additional ornaments. The story continues with what seems from the calendrical signs to be a long wait. There are now three elements. The first is a pyramid that sings, a unique representation in its type in Mesoamerica. The second is the Apoala River but now with its waters beautifully red, yellow and blue; on the bank of the river two elements emerge - on the left the glyph of a mountain and on the right the glyph of an incipient sun. The third element is a corral of stones.

The story continues with the birth of the sun, on a pyramid that now contains its songs, to let the new sun shine in all its splendour, represented by the glyph 1-flower. However, when it reaches the zenith, it is represented as a powerful warrior, who throws powerful rays like arrows. The new sun has been born, through a sacred ceremony involving the hero of the Mixtecs, 9-Wind, which brought the sacred mushrooms that were consu- med in total by eight deities of the highest rank. The story concludes with the element of duality of light and darkness, or night and day, which is characteristic of the worldview of the Mesoamerican world. The element of day and night appears first on a mountain, then on a plain, and finally, in an element full of profound symbolism, on a path.

The Codex Yuta Tnoho or Vindobonensis Mexicanus I is a pictographic document of Mixtec origin, and although it is not possible to determine precisely the date and place of its elaboration, based on its techniques of preparation and content, it is considered to date from the beginning of the 16th century, and its origin is definitely deemed pre-Hispanic. The Codex is a long screen of tanned deer hide, treated with layers of stucco such that it can be drawn on. It has 52 sheets that are approximately $22 \mathrm{~cm}$ wide by 26 long, painted on both sides. It is the most extensive pre-Hispanic document of the Mixtec culture.

Originally, the manuscript must have belonged to a ruler or high priest of "Ñuu Tnoo" (“Black City" or "Black Place”), now Santiago Tilantongo, prior to the arrival of the Spaniards. By 1521 according to some historians or 1523 according to others, 
the Codex had already arrived in Europe, which implies that it was seized and sent by the conquistadors shortly following the conquest (Jansen, 1982). After arriving in Spain, probably with Seville as the entry point, the Codex went through the hands of at least 12 different owners, in 5 countries, including popes, kings, cardinals, dukes and collectors, until after a history full of vicissitudes, including inheritance, wars, gifts and diplomacy, it was finally deposited in what is now the Austrian National Library in Vienna (Jansen et al., 1992) (Table 2).

With regard to its destination after its arrival in Spain there are two hypotheses: i) the first states that it could have been delivered by the Dominican friars to Cardinal Adriano Florensz, also known as Adriano de Utrecht, who would become Pope Adriano VI, who at the end of his Papacy would bequeath it to Pope Clement VII; ii) the second hypothesis based on an inscrip- tion of the owner that appears at the end of the Codex indicates that the first European owner was King Manuel of Portugal, who probably obtained it directly from Carlos V, who in turn would have received it as part of the Mexican treasures sent to him by Hernán Cortés. After the death of King Manuel of Portugal, in 1521, the codex became property of Giulio dei Medici who would become Pope Clement VII. However, it is known that upon his death in 1534, Pope Clement VII bequeathed the Codex to his son, Cardinal Ippolito dei Medici. Barely a year after his father's death, on August 10,1535, the cardinal died as well. The codex then passed into the hands of a Dominican of German origin, the Cardinal of Capua, Nikolaus von Schömberg, who had it until his death in 1537. It then passed into the hands of his secretary, the German humanist and philologist Johann Albrecht Windmanstetter, who took it to Bavaria, the

Table 2. Historical record of ownership changes of the Yuta Tnoho or Vindobonensis Mexicanus I Codex and geographical locations

\begin{tabular}{|c|c|c|c|}
\hline Date of ownership & Owner & City and Country & Reason of change of ownership \\
\hline \multirow[t]{2}{*}{ Before 1521} & Governor or supreme priest & Santiago Tilantongo, Oaxaca, & Unknown with certainty, probably gift \\
\hline & & Mexico & \\
\hline \multirow[t]{7}{*}{ c. 1523} & Dominic friars * & Sevilla, Spain & \\
\hline & Cardinal Adriano of Utrecht, who become later & Rome, Italy & \\
\hline & Pope Adriano VI * & & \\
\hline & Spanish King Carlos V** & Sevilla, Spain & \\
\hline & King Manuel of Portugal** & Lisboa, Portugal & Heritage \\
\hline & Giulio de Medici, who became later Pope & Rome, Italy & \\
\hline & Clement VII & & \\
\hline \multirow[t]{2}{*}{1534 to 1535} & Cardinal Ippolito dei Medici & Rome, Italy & Unknown with certainty, probably \\
\hline & & & heritage \\
\hline 1535 to 1537 & Cardinal of Capua Nikolaus von Schömberg & Capua, Italy & Unknown \\
\hline 1537 to 1557 & Johann Albrecht Widmanstetter & Baviera, Germany & Unknown \\
\hline 1558 & Duke Alberto $\mathrm{V}$ & Baviera, Germany & Obtained by purchase \\
\hline 1632 & Duke Guillermo V and Maximiliano I & Munich, Germany & Obtained by purchase \\
\hline \multirow[t]{2}{*}{1632 to 1662} & Duke Wilhelm IV & Sajonia-Weimar, Germany & Taken during the looting of the Thirty \\
\hline & & & Years' War in Munich \\
\hline \multirow[t]{2}{*}{1662 to 1667} & Juan Jorge I & Sajonia-Eisenach, Germany & Unknown with certainty, probably \\
\hline & & & heritage \\
\hline 1667 & Leopoldo I & Habsburgo, Austria & Obtained as a gift \\
\hline \multirow[t]{2}{*}{1667 to date } & National Library of Austria & Vienna, Austria & Unknown with certainty, probably gift \\
\hline & & & or donation \\
\hline
\end{tabular}


present republic of Germany. After his death on March 28, 1557, his library, including the Codex, was bought by Duke Albert V of Bavaria. Thus, the Codex arrived in Munich into the ownership of the dukes Guillermo $\mathrm{V}$ and Maximiliano I. Munich was sacked in 1632, during the Thirty Years' War, and the Codex ended up in the hands of Duke Wilhelm IV of Sachsen-Weimar. His son Prince Juan Jorge of Saxony-Eisenach presented the Codex as a gift to Emperor Leopold I of Habsburg in 1677. Since then, it has been in the Imperial Library, now the National Library of Austria, in Vienna (Adelhofer, 1963; Furst, 1978; Jansen et al., 1992).

The Codex has had 20 different names, of which the most commonly used to date has been Codex Vindobonensis Mexicanus I. However, it seems incongruous to give a Mexican codex of Mixtec origin a Latin name. The reverse side of the Codex was the last to be painted, with a pictorial tradition different from that of the obverse. The pictorial text, incomplete and made with haste and inaccuracy, contains the genealogy of the kings of Nuu Tnoo, now Santiago Tilantongo, in the Mixteca Alta of the State of Oaxaca. This place-name means "Black City”, and its hieroglyph consists of a board with frets (the sign for ñuu, "city, town, people") coloured black (tnoo). This toponymic hieroglyph is mentioned as the first site on the first page, folio 52 , on the obverse. Due to these elements, the genealogy on the reverse and the first place on the obverse, it is likely that the Codex originated in Nuu Tnoo, which was a very important city-state in the post-classical era. Additionally, a central scene in the Codex is the birth of the founders of the Nuu Dzaui dynasties of Iyadzehe Yutnu Nuu, the great mother ceiba or pochote tree, in the sacred valley of Yuta Tnoho. Given this main theme, it is preferable to call this document Codex Yuta Tnoho (pronounced in the region as Yutsa Tohon) or Apoala Codex, and this is now the officially recognized name (Jansen and Pérez-Jiménez, 2004; 2008; Wikifilologia, 2017).

In the present work, it was possible to record two pieces of evidence of the use of entheogenic fungi among the Mixtecs at present. Residents of the community of Santa Catarina Estetla mentioned that in San Antonio Huitepec, healers or shamans use mushrooms for divination or healing (Santiago et al., 2016). Additionally, Mr Domingo Hernández, also an inhabitant of the community of Santa Catarina Estetla, mentioned that Mr.
Felipe Neri Santiago, healer and inhabitant of the community of San Antonio Huitepec, once consumed hallucinogenic mushrooms or xi'i ndoto, which can translate as "fungus that awakens", to consult and solve a personal problem.

\section{DISCUSSION}

The Mixtecs are the heirs of a rich history and culture that is reflected in various codices and archaeological monuments that have survived to date. Currently, the Mixtec group is the third largest in Mexico, after the Nahuas and Mayas, with around half a million speakers (INEGI, 2010). Since pre-Hispanic times, the Mixtecs were settled in a vast territory that includes the northwest of the state of Oaxaca, the southern tip of the state of Puebla and a strip in the eastern state of Guerrero. The word mixteca comes from Nahuatl, and its meaning is "inhabitants of the Mixtlan or the place of the clouds”. In the Mixtec language, they call themselves ñuu savi ó yucu ñuu dau (davi), which means "people of the rain or place of rain" (Alavez, 1988, Mindek, 2003). The language belongs to the Otomangue language group, which also includes Zapotec, Otomi, Mazatec and Chinantec. Mixtec is a tonal language, meaning that the meaning of a word changes according to the tone used, and it has 81 linguistic variants (INALI-DOF, 2008). The Mixtecs were great creators of codices, of which the following survived destruction by the conquistadors: Yuta Tnoho, Nutall and Selden. These codices present the Mixtec worldview and its dynastic history from the seventh to the sixteenth century (Terrazas, 2017). In the Codex Yuta Tnoho, it is mentioned how the Mixtec lords performed rituals associated with corn, pulque and mushrooms that would lead to the dawn or first sunrise in the current era.

The obverse of the Codex Yuta Tnoho, painted with great precision and artistic mastery, is the only pre-Hispanic Mixtec story unmistakably related to the creation of the universe, the birth of its gods, its sacred plants and rituals, the first dawn and the order of the Mixtec world. In contrast, the reverse is elaborated with much lower quality and narrates the genealogies and historical Mixtec characters from the year 7-Flint until the year 7-House, equivalent to the years 720 to 1305 of our era (Caso, 1950). The obverse can be divided into clear narrative sections. A detailed description of these was provided by Furst (1978), who distinguished the following parts: i) the story of the 1-Deer 
couple representing the mother and father of the gods and their offspring; ii) the creation of stone objects and the birth of the deity 9-Wind or Coo Dzavui (literally the serpent of the rain), the Mixtec hero, from a flint or stone blade; iii) the birth of the Mixtec gods and nobles from a tree in Apoala or Yute Tnoho; iv) the first meeting of the gods to witness the first organization of the Mixtec world; v) the birth of corn; vi) the pulque ritual; vii) the ritual with the sacred mushrooms prior to the first dawn; and viii) the organization of the Mixtec world by the gods.

There is scant evidence on the use of hallucinogenic mushrooms by the Mixtec group. Heim and Wasson (1958) and Ravicz (1960) mentioned the use of neurotropic fungi (Psilocybe mexicana Heim) in the Mixteca Alta region; however, these authors did not indicate the communities studied. The scarcity of current use of entheogenic mushroom species of the genus Psilocybe for sacred or divinatory purposes in the Mixtec group contrasts with: i) the enormous diversity of these species in the state of Oaxaca, which includes 27 species of the 53 hallucinogenic Psilocybe species known in Mexico (Ramírez-Cruz et al., 2006), and ii) the evidence in pictographic documents such as the Yuta Tnoho Codex or Vindobonensis Mexicanus I, in which a sacred ceremony is recounted where diverse Mixtec deities consume sacred mushrooms prior to the first dawn (Caso, 1963; Furst, 1978; Jansen et al., 1992; Jansen and Pérez-Jiménez, 2007) described in detail in the present manuscript, and the Lienzo de Zacatepec or Codex Mixteco Martínez Gracida, made between 1540 and 1560 (Smith, 1973), in which a glyph shows a man with mushrooms on his head on the top of a hill, in what has been interpreted as a sacred place where ceremonies were held with mushrooms (Wasson, 1983).

A factor that could have influenced the decrease in the use of sacred mushrooms could be the religious persecution to which pre-Hispanic practices were subjected upon the arrival of Christianity in the region. The Book of Yodzo Cahi or Codex of Yanhuitlán demonstrates the use of fungi among the Mixtecs in the colonial era, a practice that led to persecution by the Catholic Church. There is a documented account of an inquisition, from 1544 to 1546, where three Mixtec Indians converted to Christianity and testified about their ostentatious worship of the pre-Hispanic gods. The most important of them rendered his declaration in Mixtec, indicating that he had ingested entheogenic mushrooms to invoke divine help on several occasions (Jiménez and Mateos, 1940).

At present, the Mixtec group has scarcely been studied from the ethnomycological point of view. The first formal study related to the biocultural importance of wild mushrooms in this group was published only recently, indicating that this group's traditional knowledge is very accurate and comparable to current scientific knowledge (Santiago et al., 2016).

\section{CONCLUSIONS}

The pictograms that appear in folios 24 and 25 of the Codex Yuta Tnoho constitute unequivocal evidence of the importance of entheogenic fungi in the Mesoamerican worldview prior to the arrival of the Spaniards. This evidence constitutes a unique piece of the cultural and ceremonial importance of said fungi in the Mixtec group. The ceremonial use of fungi currently survives in groups that are geographically close to the Mixtecs, such as the Mixes, Mazatecs and Zapotecs.

\section{ACKNOWLEDGEMENTS}

The kind support from Professor Sir David Read from the University of Sheffield in England during a sabbatical year of the author of correspondence and his invaluable comments and permanent encouraging is acknowledged. Financial support from the Project CONACyT 246674 is also acknowledged.

\section{REFERENCES}

Adelhofer, O., 1963. Codex Vindobonensis Mexicanus Österreichische National Bibliothek Wien, History and description of the manuscript. Graz. Austria, Akademische Druck und Verlagsanstalt.

Alavez, Ch.R., 1988. Toponimia Mixteca. Centro de Investigaciones y Estudios Superiores en Antropología Social. Mexico City.

Balter, M., 2014. Bones from a watery 'Black Hole' confirm first american origins. Science 344: 680-681.

Bautista-González, J.A., 2013. Conocimiento tradicional de hongos medicinales en seis localidades diferentes del país. Biol. Thesis. Universidad Nacional Autónoma de México, Mexico City.

Brotherston, G., 1995. Painted books from Mexico, British Museum Press, London.

Caso A., 1963. Representaciones de los hongos en los códices. Estudios de Cultura Náhuatl 4: 27-38.

Caso, A., 1950. Explicación del reverso del Codex Vindobonensis. Memoria del Colegio Nacional. Mexico City.

Chatters, J.C., D.J. Kennett, Y. Asmerom, B.M. Kemp, V. Polyak, A.N. Blank, P.A. Beddows, E. Reinhardt, J. Arroyo-Cabrales, D.A. Bolnick, R.S. Malhi, B.J. Culleton, P.L. Erreguerena, D. Rissolo, S. Morell-Hart, T.W. Jr Stafford, 2014. Late pleistocene human skeleton and mtDNA link paleoamericans and modern native americans. Sciences 344: 750-754. 
Christenson, A.J., 2003. Popol Vuh: Sacred Book of the Quiché Maya People. Norman, University of Oklahoma Press, Oklahoma.

Ferdinand, A., M. Jansen, G.A. Pérez-Martínez, 1992. Origen e historia de los reyes mixtecos, libro explicativo del llamado Códice Vindobonensis, Codex Vindobonensis Mexicanus 1 Österreichische National bibliothek, Viena. Sociedad Estatal Quinto Centenario, Madrid, Fondo de Cultura Económica. Mexico City.

Florescano, E., 1997. El mito nahua de la creación del cosmos y el principio de los reinos. In: La palabra y el hombre. Universidad Veracruzana 104: 57-70.

Furst, JL., 1978. Codex Vindobonensis Mexicanus I: a commentary. State University of New York at Albany, Institute for Mesoamerican Studies, New York.

Garibay-Orijel, R., J. Cifuentes, A. Estrada-Torres, J. Caballero, 2006. People using macro-fungal diversity in Oaxaca, Mexico. Fungal Diversity 21: 41-67.

Garza, M. de la., 1983. Análisis comparativo de la historia de los mexicanos por sus pinturas y la leyenda de los soles. Estudios de Cultura Náhuatl 16: 123-134.

Guzmán, G., 1997. Los nombres de los hongos y lo relacionado con ellos en América Latina. Comisión Nacional para el Conocimiento y Uso de la Biodiversidad, Instituto de Ecología. Xalapa, Ver.

Guzmán, G., 2008. Hallucinogenic mushrooms in Mexico: an overview. Economic Botany 62: 404-412.

Heim, R., R.G. Wasson, 1958. Les champignons hallucinogènes du Mexique: études ethnologiques, taxinomiques, biologiques, physiologiques et chimiques. Muséum National d'Histoire Naturelle, Paris.

Hernández-Santiago, F., J. Pérez Moreno, B. Xoconostle Cázares, J.J. Almaraz Suárez, E. Ojeda Trejo, G. Mata, I. Díaz Aguilar, 2016. Traditional knowledge and use of wild mushrooms by Mixtecs or Nuu savi, the people of the rain, from Southeastern Mexico. Journal of Ethnobiology and Ethnomedicine 12: 35(1-22).

Humboldt, A. von., 1816. Vues des cordillères, et monuments des peuples indigènes de l'Amerique, Tome Premier, Paris.

INALI-DOF, 2008. Catálogo de las Lenguas Indígenas Nacionales: Variantes Lingüísticas de México con sus autodenominaciones y referencias geoestadísticas. Instituto Nacional de Lenguas Indígenas-Diario Oficial de la Federación, Mexico City. available at : http://www.cdi.gob.mx/lenguamaterna/catalogo_lenguas_ indigenas_mexico_2008.pdf. [Retrieved on october 15, 2017].

INEGI, 2010. Censo de Población y Vivienda, México Instituto Nacional de Estadística, Geografía e Informática. Mexico City.

Jansen, M., 1982. Huisi Tacu, estudio interpretativo de un libro mixteco antiguo: Codex Vindobonensis Mexicanus I. Ph. D. thesis. Amsterdam, Centrum voor Studie en Documentatie van Latijns Amerika.

Jansen, M., G.A. Pérez-Jiménez, 2004. Renaming the Mexican Codices. Ancient Mesoamerica 15: 267-271.

Jansen, M., G. A. Pérez-Jiménez, 2007. Encounter with the Plumed Serpent. Boulder, CO, University Press of Colorado.

Jansen, M., G. A. Pérez-Jiménez, 2008. Paisajes sagrados: códices y arqueología de Ñuu Dzaui. Revista Itinerarios 8: 83-112.

Jansen, M.E.R.G.N., F. Anders, A. Pérez-Jiménez, 1992. Origen e historia de los reyes mixtecos. Libro explicativo del llamado Códice Vindobonensis. Fondo de Cultura Económica. Mexico City.

Jiménez, M.W., H.S. Mateos, 1940. Códice de Yanhuitlán (est. prel.), ed. facs. Museo Nacional, Mexico City.

Jonghe, E. de, 1905. Histoyre du Mechique. Manuscrit français inédit du XVIe siècle. Journal de la Société des Américanistes. Nouvelle Série 2: 1-41.

Krickeberg, W., 2012. Mitos y leyendas de los aztecas, incas, mayas y muiscas. Translation of the first edition of the work: Marchen der Azteken und Inkaoeruaner, Maya und Muisca (1928), Fondo de Cultura Económica, Mexico City.

Lejeal, L., 1902. Les antiquités mexicaines. Bibliotèque de Bibliographies critiques publiée par la Societe des Etudes Historiques, Paris.

León-Portilla, M., 2006. La filosofía náhuatl estudiada en sus fuentes. 10th edition. Instituto de Investigaciones Históricas/Universidad Nacional Autónoma de México, Mexico City.

Leyenda de los soles, 1558. Continuada con otras leyendas y noticias, relación anónima escrita en lengua mexicana en el año 1558". Mexico, available at: http://cdigital.dgb.uanl.mx/ la/1080012504/1080012504.PDF [Retrieved on october 20, 2017].

Mindek, D., 2003. Mixtecos. Pueblos indígenas del México contemporáneo. Comisión Nacional para el Desarrollo de los Pueblos Indígenas (CDI), Programa de las Naciones Unidas para el Desarrollo (PNUD). Mexico City.

Moreno de los Arcos, R., 1967. Los cinco soles cosmogónicos. Estudios de Cultura Náhuatl 7:183-210.

Pérez-Moreno, J., A. Lorenzana Fernández, V. Carrasco Hernández, A. Yescas-Pérez, 2010. Los hongos comestibles silvestres del Parque Nacional Izta-Popo, Zoquiapan y Anexos. Colegio de Postgraduados, SEMARNAT, CONACYT. Texcoco, Mexico.

Pérez-Moreno, J., M. Martínez-Reyes, 2014. Edible ectomycorrhizal mushrooms: biofactories for sustainable development. In: Guevara-Gonzales, R., I. Torres-Pacheco (eds.). Biosystems engineering: biofactories for food production in the century XXI. Springer International Publishing Switzerland, Cham.

Pérez-Moreno, J., M. Martínez-Reyes, A. Yescas-Pérez, A. DelgadoAlvarado, B. Xoconostle-Cázares, 2008. Wild mushroom markets in central Mexico and a case study at Ozumba. Economic Botany 62: 425-436.

Ramírez-Cruz, V., G. Guzmán, F. Ramírez-Guillén, 2006. Las especies del género Psilocybe conocidas del estado de Oaxaca, su distribución y relaciones étnicas. Revista Mexicana de Micología 23: 27-36.

Ravicz, R., 1960. La Mixteca en el estudio comparativo del hongo alucinante. Anales del Instituto Nacional de Antropología e Historia 13: 73-92.

Recinos, A., 1960. Popol Vuh: las antiguas historias del Quiché. Fondo de Cultura Económica. Mexico City.

Ruan-Soto, F., J. Cifuentes, R. Mariaca, F. Limón, L. Pérez-Ramírez, S. Sierra, 2009. Uso y manejo de hongos silvestres en dos comunidades de la Selva Lacandona, Chiapas, México. Revista Mexicana de Micología 29: 61-72.

Scherzer, C., 1857. Las historias del origen de los indios de esta provincia de Guatemala, traducidas de la lengua quiche al castellano para más comodidad de los ministros del S. Evangelio por el R. P. F. Francisco Ximenez. (Translation of the work by Ximenez F. in 1721). Academia Imperial de Ciencias, Vienna.

Schultes, R.E., A. Hofmann, 2000. Plantas de los dioses. Fondo de Cultura Económica. Mexico City.

Smith, M.E., 1973. Picture Writing from Sothern Mexico; Mixtec place Signs and Maps. University of Oklahoma Press, Norman, Oklahoma.

Terrazas, T.D., 2017. El mito de origen mixteco: larga duración del texto-código-ritual en la memoria de la cultura. Revista Chilena de Semiótica 7: 81-95.

Wasson, R.G., 1983. El hongo maravilloso: Teonanacatl. Micolatría en Mesoamérica. Fondo de Cultura Económica, México City.

Wikifilología, 2017. Códice Yuta Tnoho. Sitio web para la publicación, consulta, análisis y discusión de documentos de la tradición mesoamericana. Instituto de Investigaciones Filológicas, Universidad Nacional Autónoma de México, Mexico City, available at: http://www.iifilologicas.unam.mx/wikfil/index.php/Yuta Tnoho,_Códice _[Retrieved on october 20, 2017]. 